\title{
Selenium Nephroprotection through Inhibition of PERK- EIF2a- CHOP Pathway in Lead Intoxicated Male Rats
}

\author{
Marwa M Rashed ${ }^{1}$, Mangoud M. EI Wakel, Mohammed Z. Hussin', Wesam M EL Bakly ${ }^{3}$, \\ ${ }^{1}$ Crime Investigation Research Department, National Center for Social and Criminological Research, Cairo Egypt. \\ ${ }^{2}$ Environmental Research Department, National Center for Social and Criminological Research, Cairo Egypt. \\ ${ }^{3}$ Pharmacology Department, Faculty of Medicine, Ain Shams University, Cairo Egypt.
}

\begin{abstract}
Background: Lead contamination has turned into a major concern as it serves no useful purpose in the human body. Its presence in the body can lead to toxic effects on different organs. Aim: The purpose of the present study is to examine the efficacy of selenium in mitigating leadinduced oxidative stress and kidney injury in male albino Wistar rats. Further to study the underlying molecular mechanism. Methods: We hypothesized that selenium protect against lead nephrotoxicity by testing various parameters of kidney function in male rats treated for 28 days with $0.5 \mathrm{mg} / \mathrm{kg}$ selenium versus control male rats that received a vehicle. Results: The results showed an increase of serum urea, creatinine, uric acid and urinary albumin in rats intoxicated with lead compared to control group. The increase of these parameters would indicate renal toxicity which is confirmed by histopathological changes. Lead intoxicated rats had significant increment in apoptosis as well as phosphorylated PERK, eIF2 $\alpha$ and apoptotic proteins as CHOP, caspase 3 and 8 in the kidneys, which were attenuated by selenium treatment. Conclusion: This study clearly demonstrated that activation of PERK- eIF2 $\alpha$-CHOP signaling pathway was involved in lead induced nephrotoxicity in rats and selenium inhibited lead nephrotoxicity partly through suppression of PERK- eIF $2 \alpha$ CHOP pathway.
\end{abstract}

Key words Lead nephrotoxicity- selenium- nephroprotection- PERK- eIF2 $\alpha$-CHOP pathway- caspase

\section{Introduction}

$\mathrm{L}$ ead $(\mathrm{Pb})$, an environmental toxin, is commonly used in different fields, such as paints, ceramic and petroleum products. Nowadays, contamination with $\mathrm{Pb}$ has turned into a major concern. Lead serves no useful purpose in the human body. Its presence in the body can lead to toxic effects on different organs, regardless of age, gender, or method of exposure. Lead is distributed and stored in nearly all organs and mainly renally eliminated; so kidneys will be exposed to its toxic effects. Therefore, nephrotoxicity has been reported as one of the most important silent feature of lead toxicity (Fioresi et al., 2014; Orisakwe, 2014).

On a molecular level, proposed mechanisms for nephrotoxicity is mediated via oxidative degradation of polyunsaturated fatty acids, causing impairment in membrane function and its structural integrity, decrease in fluidity, inactivation of a number of membranebound enzymes. Lead induced nephrotoxicity is mainly proximal tubular nephropathy, glomerular sclerosis, and interstitial fibrosis. The proximal tubular cells are particularly susceptible for the toxic effect as their functions need high energy. Clinically, excessive lead exposure is associated with include low- and highmolecular weight proteinuria, impaired transport of organic anions and glucose and depressed glomerular filtration rate (Sidhu et al., 2004; Diamond, 2005; Missoun et al., 2010).
Autophagy and apoptosis constitute two distinct cellular processes for cellular turnover and destruction. It was suggested that accumulation of unfolded proteins in the endoplasmic reticulum (ER) play a role in acute and chronic kidney disease. A major response to ER stress is the activation of three major signaling pathways: protein kinase $\mathrm{R}$ (PKR)-like endoplasmic reticulum kinase (PERK), inositol-requiring protein 1 (IRE-1) and activating transcription factor 6(ATF6). PERK interacts with a wide range of misfolded proteins to regulate protein synthesis, which is involved in the pathological mechanism of kidney diseases. It can induce the expression of CCAAT/enhancer-binding protein $(\mathrm{C} / \mathrm{EBP})$ homologous protein $(\mathrm{CHOP})$, which plays an important role in ER stress-induced apoptosis (Oyadomari and Mori, 2004; Walter and Ron, 2011; Stanifer et al., 2014; Cybulsky, 2017).

Chelating agents are the only available way of treatment for $\mathrm{Pb}$ poisoning. However, their use cannot remove metals from intracellular sites. In fact, it may cause essential metal loss, and renal dysfunction. In addition, management challenge is affected by the high cost and lack of availability of these agents. Continuous search for widely available "natural antidotes" that will ameliorate or reverse the deleterious effects of lead has been research focus. There is a positive correlation between dietary supplementation with certain vegetables and the reduction of toxic effects of heavy metals (Flora \&Pachauri, 2010; Sharma et al., 2010). 
Selenium (Se) is an essential trace element. It is a component of some selena proteins and enzymes like glutathione peroxidase. Selenium compounds are antioxidants which are much more potent than other antioxidants like vitamin E and vitamin C (El-Ghazaly et al., 2016). Also, Se has anti-inflammatory and antiapoptotic effects (Demirci et al., 2017). Selenium is frequently used in animal models of experimentally induced nephrotoxicity (Soudani et., 2011). To our knowledge, the possible effects of Se on lead-induced renal damage have not been investigated yet. Based on this information, the purpose of the present study is to examine the efficacy selenium in mitigating chronic lead-induced oxidative stress and injury in the kidney of male albino Wistar rats. Further to study the underlying molecular mechanism.

\section{Materials and Methods}

\section{Drugs and chemicals:}

Selenium was obtained from a local pharmacy. Lead acetate was purchased from El- Gomhouria Company for Trading Chemicals and Medical Appliances, Egypt. Creatinine, urea, uric acid, MDA, and TAC testing kits, in addition to urinary albumin ELISA kit were purchased from Bio-diagnostic Co., Giza, Egypt. PERK, eIF2 $\alpha$, CHOP, caspase $3 \& 8$ ELISA kit were from Cusabio, Wuhan, China.

\section{Animals and Experimental Design:}

Thirty-two male Wister rats weighed from 150$200 \mathrm{~g}$ were purchased from National Research center, El Dokki, Egypt. Rats were allowed at least one week to acclimatize to the lab conditions. A 12/12-hour light/dark cycle was maintained with light on at 6 am and off at $6 \mathrm{pm}$, Temperature was maintained at $25^{\circ} \mathrm{C}$. Animals were housed, diet and water were provided ad libitum, and all procedures were done according to Research Ethics Committee of Faculty of Medicine, Ain Shams University.

Animals were randomly divided into four groups of 8 rats. Group I received $1 \mathrm{ml}$ of distilled water orally for 28 days and served as control group; Group II was received oral administration of $0.5 \mathrm{mg} / \mathrm{kg}$ of selenium for 28 days. Group III (lead intoxicated rats) was exposed to lead acetate through drinking water for 28 days and served as the lead control group; Group IV was exposed to lead through drinking water and received oral $0.5 \mathrm{mg} / \mathrm{kg}$ of selenium concomitantly for 28 days; The dose of selenium was selected based on previous studies (Kiełczykowska et al., 2015).

Preparation of leaded water $(0.2 \%$ lead): $5 \mathrm{~g}$ of lead acetate $(\mathrm{CH} 3 \mathrm{COO}) 2 \mathrm{~Pb} \cdot 3 \mathrm{H} 2 \mathrm{O})$ was dissolved in $2.5 \mathrm{~L}$ of distilled water (Abdulmajeed et al., 2015).

\section{Physiological assessment}

Body weights of rats were recorded weekly during the study. After 4 weeks, body weights were recorded and the kidneys were collected and weighed.

\section{Urine and Blood Collection and Tissue Processing}

Rats were weighed at the beginning and end of the experiment. The animals were placed in metabolic cages one day before sacrifice, and the amount of urine voided during the $24 \mathrm{~h}$ was collected. Collected urine was stored deep frozen $\left(-80^{\circ} \mathrm{C}\right)$ after its volume had been recorded. Animals were anaesthetized using urethane at dose $1.2 \mathrm{~g} / \mathrm{kg}$ (Silva et al., 2001) and blood was collected retro-orbital venous plexus centrifuged at $5{ }^{\circ} \mathrm{C}$ to separate plasma. The plasma collected was frozen at $-80{ }^{\circ} \mathrm{C}$ pending analysis. Kidneys were removed and washed in saline, weighed and a small portion of the upper part of the right kidney was excised and placed in formalin for subsequent histopathology. The remainder of the right kidney and the left kidney were individually wrapped in aluminum foil and stored at a temperature of $-80{ }^{\circ} \mathrm{C}$, pending analysis. For preparation of renal homogenates, $100 \mathrm{mg}$ of kidney tissue was homogenized on ice in $1 \mathrm{~mL}$ of homogenization buffer $(50 \mathrm{mM}$ Tris- $\mathrm{HCl}, 180 \mathrm{mM}$ $\mathrm{KCl}, 10 \mathrm{mM}$ EDTA, $\mathrm{pH}$ 7.4).

\section{Biochemical assessment:}

Kidney function was assessed by measuring serum uric acid, urea, and creatinine. Serum uric acid was determined according to the method described by Whitehead et al, (1991), while urea was determined according to Coulombe and Favreau, (1963), and serum creatinine was assessed according to the reaction described by Larsen, (1972).

Furthermore, 24-h urine collection for urine albumin measurement is gold standard method to microalbuminuria screening urinary albumin $(\mathrm{mg} / 24 \mathrm{~h}$ ) levels were determined using enzyme-linked immunosorbent assay kits according to the manufacturer's instructions (BioSystems, Spain).

\section{Tissue assessment:}

Determination of Malondialdehyde (MDA) and Total Antioxidant Capacity (TAC) were estimated calorimetrically according to Ohkawa et al. (1979) and Koracevic et al. (2001) respectively.

The concentration of renal p-ERK, eIF $2 \alpha$, and CHOP were measured using Rat ELISA Kit (Catalog No: MBS2511166, MBS751823, MBS3808179, respectively, MyBioSource, Egypt). Caspase $3 \& 8$, were evaluated by ELISA according to the ELISA kit instructions (CSB-E08857r, MBS088250, respectively, MyBioSource, Egypt).

\section{Histopathological evaluation}

Kidneys were fixed in Bouin's solution. They were embedded in paraffin, sectioned and stained with hematoxylin-eosin for histological investigation. Three slides were prepared from each kidney. All sections were evaluated semi-quantitatively for the degree of injury. All sections were estimated for the degree of tubular and glomerular injuries. Class 0: no injury; class 1: $<25 \%$ injury; class 2: $25-50 \%$ injury; class 3: $>50 \%$ injury.

\section{Statistical analysis}

Data were expressed as mean \pm standard deviation (SD). Statistical analysis was carried out with one-way analysis of variance (ANOVA) followed by Tukey post hoc test. Values of $\mathrm{p}<0.05$ were considered to be significant. Graphpad prism software (version 5) (Graphpad Software Inc., USA) was utilized and a probability level of less than 0.05 was believed to be statistically significant 


\section{Results}

Effects of selenium treatment on Body weight, relative kidney weight, water intake and urine volume in lead-intoxicated rats:

Normal control rats showed increase in body weight by about $36 \%$ of their initial body weight. Compared with the normal control group, there was a significant decrease $(\mathrm{P}<0.05)$ by $63 \%$ in the body weight change in lead-intoxicated group. Treatment with selenium caused significant increase by $163 \%$ in body weight compared with the lead intoxicated group. Selenium control group and selenium treated group showed non-significant change in body weight compared with the normal control group.

The relative kidney weight was significantly increased by $46 \%$ in lead intoxicated rats compared with the control $(\mathrm{P}<0.05)$, and treatment with selenium significantly reduced the relative kidney weight by $\% 26 \%(\mathrm{P}<0.05)$. There was no notable change in water intake and urine volume among the groups (Table 1).

Effects of selenium treatment on kidney functions in lead-intoxicated rats:

Lead intoxicated rats showed a statistically significant $(\mathrm{P}<0.05)$ increase in the urinary albumin, serum urea, uric acid, and serum creatinine by $51 \%$, $90 \%, 220 \%, 84 \%$, respectively. In contrast, treatment with selenium significant decrease in urinary albumin, serum urea, uric acid and serum creatinine by $38 \%$, $46 \%, 65 \%, 15 \%$, respectively (Table 2 ).

Effects of selenium treatment on the histological structures of the kidney in lead intoxicated rats:

Histopathologically, kidney tissue appears normal architecture of the renal cell in both control and group treated with selenium alone. In contrast, remarkable tubule injury, massive necrosis, infiltration of inflammatory cells, vacuolar degeneration and intraluminal hyaline casts were observed in kidney sections from rats intoxicated with lead acetate. On the other hand, the administration selenium was able to improve in all the parameters of renal tissue damage and inflammation evoked by lead acetate (Figure 1).

Effects of selenium treatment on MDA, total antioxidants, and caspase 3 and 8 in leadintoxicated rats:

Lead intoxicated rats showed increase in renal MDA by $203 \%$ and decrease in renal TAC by $139 \%$ compared to normal control rats. Treatment with selenium significantly reduced renal MDA by $63 \%$ and increase renal TAC by $50 \%$ compared to lead intoxicated rats (Figure 2).

Moreover, figure (2) showed that in the lead intoxicated group significant increase in renal tissue caspase $3 \& 8$ by $51 \%$ and $97 \%$, respectively compared to the control group $(\mathrm{P}<0.05)$. in contrast, Treatment with selenium markedly reduced renal tissue caspase $3 \& 8$ by $36 \%$ and $58 \%$, respectively compared to lead intoxicated group $(\mathrm{P}<0.05)$.

Effects of selenium treatment on activated PERKeIF2 $\alpha$-CHOP pathway in lead intoxicated rats:

Lead intoxicated rats showed a significant increase in the tissue content of p-PERK (Figure 3A), peIF $2 \alpha$ (Figure 3B), and CHOP (Figure 3C) by $128 \%$, $56 \%$, and $111 \%$, respectively. Conversely, selenium significantly decreased the elevated concentrations by $46 \%, 32 \%$, and $43 \%$, respectively compared to lead intoxicated rats.

Table (1): Effect of selenium treatment on some basic physiological parameters in lead intoxicated rats

\begin{tabular}{|c|c|c|c|c|}
\hline Parameters & Control & Selenium & Lead intoxicated & Selenium /Lead intoxicated \\
\hline Change in body weight \% & $36.00 \pm 9.90$ & $37.220 \pm 5.3$ & $13.22 \pm 4.4^{*}$ & $34.78 \pm 17.6^{\#}$ \\
\hline Relative kidney weight \% & $0.465 \pm 0.05$ & $0.488 \pm 0.02$ & $0.687 \pm 0.1^{*}$ & $0.503 \pm 0.04^{\#}$ \\
\hline Water intake (ml) & $2.100 \pm 0.08$ & $2.060 \pm 0.11$ & $2.060 \pm 0.23$ & $1.94 \pm 0.32$ \\
\hline Urine volume (ml) & $1.080 \pm 0.08$ & $1.100 \pm 0.01$ & $2.0 \pm 0.018^{*}$ & $1.50 \pm 0.07^{\#}$ \\
\hline
\end{tabular}

Values in the tables are means $\pm S D(n=8)$, *Denotes significance of different groups vs. Control group: $P<0.05$,

\# Denotes significance of different groups vs Lead intoxicated group: $P<0.05$

Table 2: Effect of selenium treatment on kidney functional tests in lead intoxicated rats.

\begin{tabular}{|c|c|c|c|c|}
\hline Parameters & Control & Selenium & Lead intoxicated & $\begin{array}{c}\text { Selenium /Lead } \\
\text { intoxicated }\end{array}$ \\
\hline Serum creatinine mg/dl & $0.413 \pm 0.06$ & $0.428 \pm 0.06$ & $0.760 \pm 0.08 *(84 \%)$ & $0.648 \pm 0.05^{\#(15 \%)}$ \\
\hline Serum urea mg/dl & $23.80 \pm 3.03$ & $21.6 \pm 1.1$ & $45.17 \pm 1.70 *(90 \%)$ & $24.33 \pm 3.30^{\#(46 \%)}$ \\
\hline Serum uric acid mg/dl & $1.300 \pm 0.10$ & $1.44 \pm 0.3$ & $4.183 \pm 0.50 *(220 \%)$ & $1.480 \pm 0.19^{\#(65 \%)}$ \\
\hline Urinary Albumin g/L & $8.22 \pm 0.6$ & $7.06 \pm 0.2$ & $12.42 \pm 0.60 *(51 \%)$ & $7.660 \pm 0.40^{\#(38 \%)}$ \\
\hline
\end{tabular}

Values in the tables are means $\pm S D(n=8)$, *Denotes significance of different groups vs. Control group: $P<0.05$.

${ }^{*}$ Denotes significance of different groups vs Lead intoxicated group: $P<0.05$ 


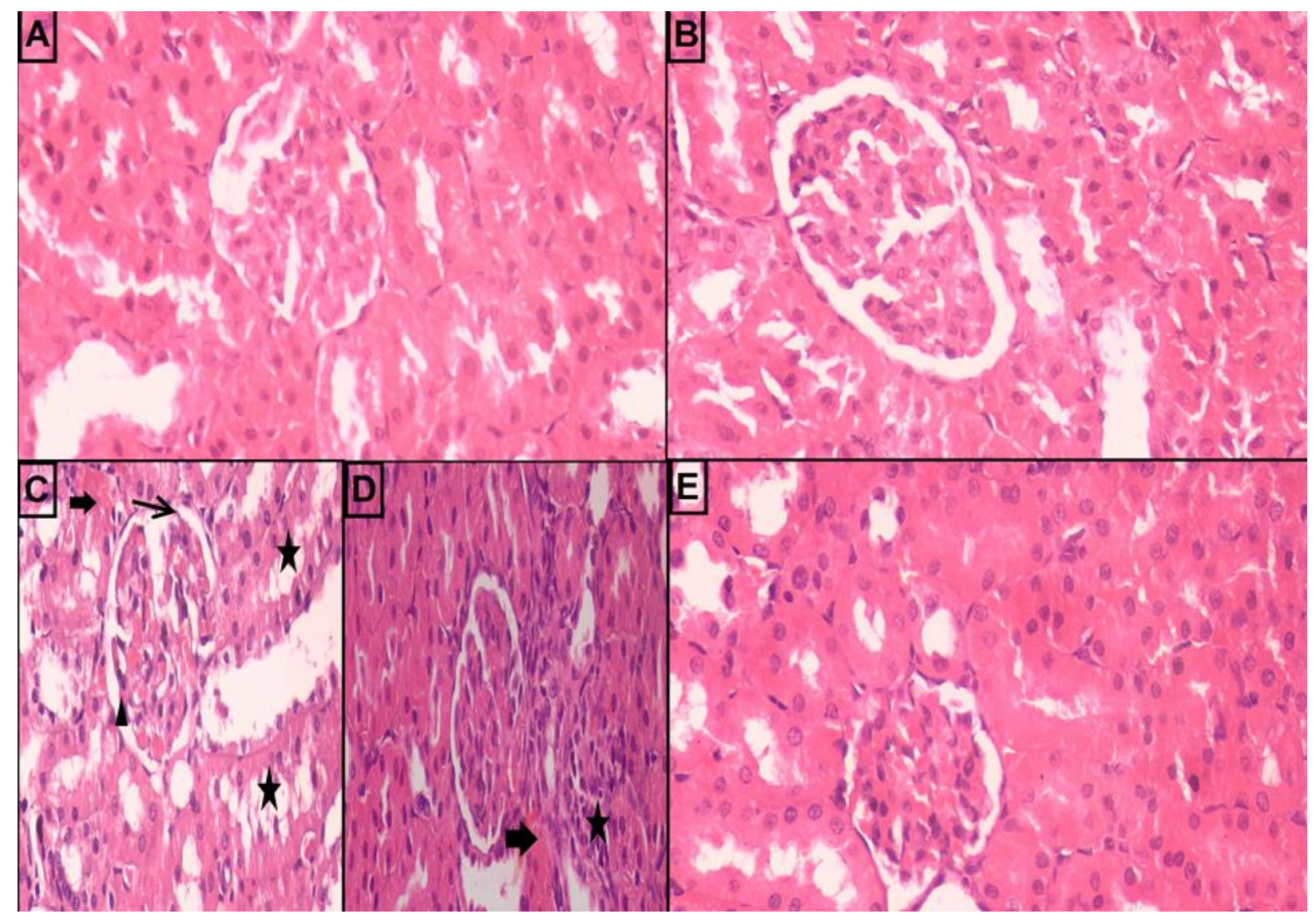

Figure (1): Photomicrographs of hematoxylin and eosin-stained histological sections of rat kidney tissue: (A \&B): Control and selenium group: kidney tissue with normal histological structure. (C): Lead acetate-treated group: tubular epithelium with glomerular necrosis (thin arrows), hemorrhage (arrows), vacuolation of cytoplasm (star) and glomerular atrophy (triangle). (D): Lead acetate-treated group showing mononuclear cell infiltration in interstitial areas (stars) and sever hemorrhage (arrow). (E): Lead acetate + selenium- treated group showing the glomeruli and the renal tubules appeared more or less normal. 

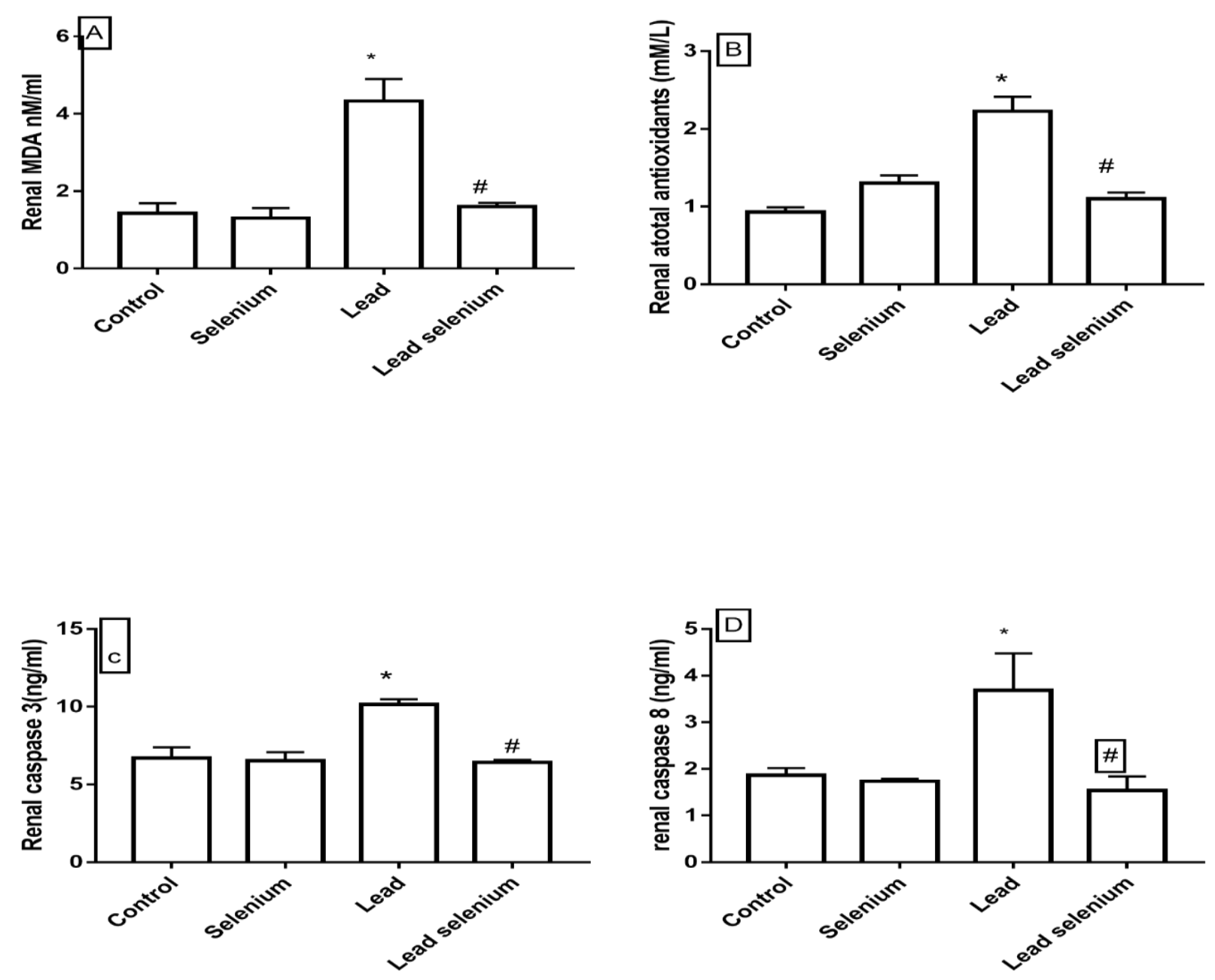

Figure 2: Effects of selenium treatment on MDA, total antioxidants, and caspase 3 and 8 in lead intoxicated rats. The rats were treated with $1 \% \mathrm{~Pb}$ acetate for 28 days. Selenium was orally administered in a dose of $0.5 \mathrm{mg} / \mathrm{kg}$ of for 28 days. Bars represent means \pm SD $(n=8)$. (A). Renal Malondialdehyde (MDA). (B). Renal Total Antioxidant Capacity (TAC). (C). Renal caspase3. (D). renal caspase8.Data was analyzed by one-way ANOVA using Tuckey's post hoc test. * $\mathbf{p}<\mathbf{0 . 0 5}$,) compared with control group, ${ }^{\#}<0.05$ compared with lead group. 

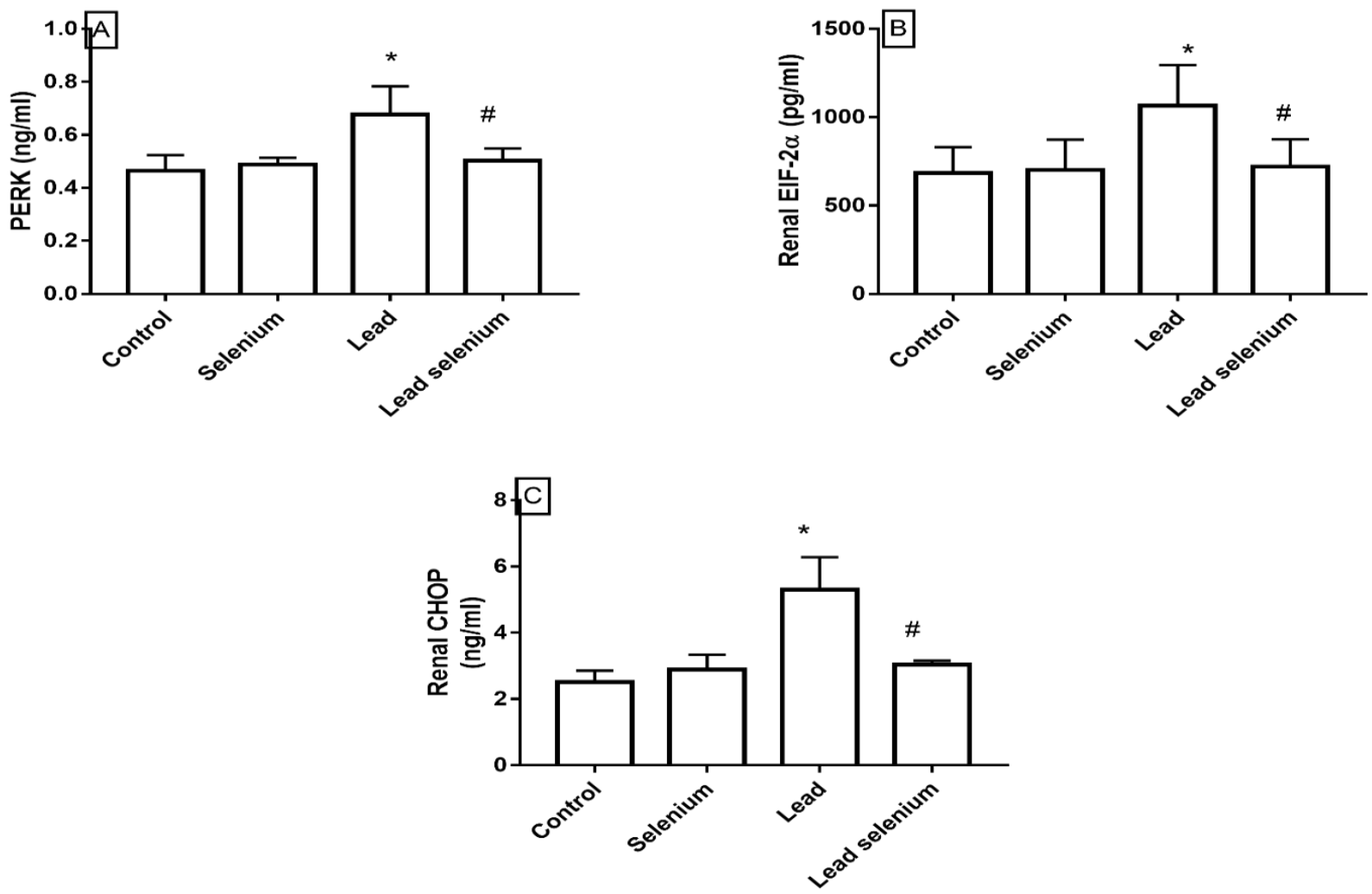

Figure (3): Effects of selenium treatment on Pb-activated PERK-eIF2 $\alpha$ - CHOP pathway in Pb-induced nephrotoxicity in rats: The rats were treated with $1 \% \mathrm{~Pb}$ acetate for 28 days. Selenium was orally administered in a dose of $0.5 \mathrm{mg} / \mathrm{kg}$ of for 28 days. Bars represent means \pm SD $(n=8)$. (A). PERK. (B). Renal eIF-2a. (C). Renal CHOP pathway. Data was analyzed by one-way ANOVA using Tuckey's post hoc test. *p<0.05,) compared with control group, ${ }^{\#} \mathbf{p}<0.05$ compared with lead group.

\section{Discussion}

Chronic lead exposure is extremely toxic and disturbs various cellular functions and many organs, including the kidney producing chronic interstitial nephritis. Lead nephropathy is most likely to occur in high-risk groups for kidney disease, including hypertensive and diabetic patients (Al-Megrin et al. 2019). Chronic prolonged lead exposure at lower levels may represent a global public health concern and still contribute to kidney toxicity. However particularly in developed countries, the high level of lead exposure is now increasingly rare due to removal of lead from environmental sources and occupational controls (Ekong et al., 2006).

Until now, treatment is directed toward minimizing further exogenous lead sources and chelation therapy based on blood lead levels and symptoms, but excretion of lead via the kidneys is also a potential concern (Flora \&Pachauri, 2010). Therefore, the present study was designed to investigate the nephron-protective effect of selenium against lead induced renal injury in rats. Lead exposure caused a significant rise in the renal index, as well as an elevation in serum urea, uric acid, creatinine levels and urinary albumin. In previous studies, glomerular effects of chronic lead exposure range from an increased prevalence of high molecular weight proteinuria to a nephrotic syndrome (Lin et al., 2001, Nikolas et al., 2005). However, clinically patients usually present with an elevated serum creatinine, uric acid, urea, but with little or no associated proteinuria. Generally, these manifestations are non-specific, and may be confused with hypertensive nephrosclerosis or chronic urate nephropathy. The increased suspicion for lead nephropathy depend on the presence of manifestation of other organ lead toxicity (Rastogi, 2008). All these changes were ameliorated by selenium $0.5 \mathrm{mg} / \mathrm{kg}$ in the present work. Previous research had shown that selenium could normalize disturbed kidney function markers (Hematil et al. 2012). Previous studies have demonstrated the association between the decrease in plasma selenium level and acute as well as chronic kidney disease (Makropoulos et al., 1997 \& Zachara et al., 2004). These changes were confirmed by histopathological evaluation of renal tissue. Therefore, selenium could be a useful therapeutic drug to inhibit the progression of lead-induced nephrotoxicity.

MDA is one of the most important biomarkers in oxidative damage, antioxidant defense systems including reduced glutathione (GSH) antioxidant mechanisms (Zhang et al., 2012). Our results suggested that oxidative stress was involved in the pathophysiology of lead induced nephrotoxicity. As observed by increase in MDA level, as well as decreased TAC in lead intoxicated rats, both were 
consistently relieved by selenium treatment. Selenium is a trace element that is considered as a cofactor for several enzymes including antioxidant defenses. It was established that, selenium supplementation in renal impaired patients, reduces the products of oxidative stress (Iglesias et al., 2013). Thus, the antioxidant properties of selenium appeared to underlie the nephron-protective effects against kidney injury induced by lead.

Moreover, oxidative stress can induce autophagy, a cell survival response, mostly during exposure to modest doses of reactive oxygen species (ROS), although it can lead to cell death or apoptosis. Apoptosis can be triggered by three main signaling pathways involving death receptors localized at the cell surface (Green and LIambi, 2015), or intrinsic pathways involving mitochondria or the ER (Jin and El-Deiry, 2005). Recent studies have shown that ER stress-mediated PERK pathway plays a key role in the pathological mechanism of renal diseases (Rutkowski and Kaufman, 2007). A positive association was found between the development of oxidative stress and apoptosis after lead exposure. The kidney is highly susceptible to the development of oxidative insults due to its long polyunsaturated fatty acids content (Yin et al. 2019). This trend was confirmed in our study, as indicated by the increased level of caspase 3,8 as well as the increase in CHOP protein in the renal tissue in response to lead exposure which were consistently ameliorated by selenium administration confirming its protective role in lead-induced nephrotoxicity.

Apoptosis might play a role in lead-induced nephrotoxicity (Gao et al., 2013). The involvement of ER stress in the pathophysiology of lead induced nephrotoxicity is a relatively new area of research. Targeting inhibition of ER stress may provide new therapeutic approaches for protection. ER stress is an important mechanism involved in response to toxic stimuli in renal tubular cells (Ding et al., 2015). Moderate stress assists tubular cells to support their repair, while persistent ER stress results in the activation of ER-specific apoptosis mediator, to initiate the programed cell death (Harding et al., 2000). ER stress causes apoptosis through three different signal pathways, PERK-eIF2 $\alpha$-ATF4-CHOP pathway, IRE1 $\alpha$ XBP1 pathway and ATF6 pathway (Ogbechi et al., 2018). Since PERK branch has a significant role in the pathogenesis of renal diseases we primarily investigated the role of PERK pathway in nephroprotective effect of selenium. In this study, lead intoxicated rats were found to have increased phosphorylated PERK, eIF2 $\alpha$, CHOP, which were significantly blunted by selenium treatment.

The cellular stress response related to endoplasmic reticulum unfolded protein responses is activated due to accumulation of unfolded proteins in the lumen of the endoplasmic reticulum. It has three aims to restore normal function of the cell by halting protein translation, degrading misfolded proteins, and activating the signaling pathways to produce chaperones involved in protein folding. Within a certain time, if failed it will induce apoptosis. In conditions of prolonged stress, the PERK protein becomes activated by autophosphorylation. p-PERK phosphorylates eIF2 $\alpha$ which represses eIF2B, resulting in reduced ER load through inhibition of global protein synthesis and induction of cytoprotective genes by preferentially stimulating translation of ATF4 (Huang et al., 2016). ATF4 also enhances the expression of CHOP, which negatively regulates p-eIF2 $\alpha$ levels through the production of GADD34 that binds PP1 and dephosphorylates eIF2 $\alpha$. Also, our study provided an evidence that selenium can effectively ameliorate PERK activation in response to ER stress Thus PERKeIF2 $\alpha$-ATF4-CHOP axis of the ER stress response contributes to nephroprotective effect of selenium in lead-induced nephrotoxicity and apoptosis (Liu et al., 2016).

\section{Conclusion}

Selenium inhibited ER stress-induced renal apoptosis and ameliorated structural and functional abnormalities in lead intoxicated rats. The protective effect was associated with the inhibition of PERK- eIF2 $\alpha$,-CHOP pathway. Selenium might be a novel drug for prevention of lead induced nephrotoxicity through suppression of renal ER stress.

\section{Acknowledgement}

This work was supported by research grant from National Center for Social and Criminological Research, under the Environmental Pollutants Research Program.

\section{References}

Abdulmajeed W, Sulieman HB, Zubayr MO, et al., (2015): Honey prevents neurobehavioral deficit and oxidative stress induced by lead acetate exposure in male wistar rats- a preliminary study. Metab Brain Dis;31(1): 37-44.

Al-Megrin WA, Alkhuriji AF, Yousef AOS, et al., (2019): Antagonistic Efficacy of Luteolin against Lead Acetate Exposure-Associated with Hepatotoxicity is Mediated via Antioxidant, Anti-Inflammatory, and Anti-Apoptotic Activities. Antioxidants (Basel);9(1): 10.

Coulombe JJ, Favreau L (1963): A new simple semimicro method for colorimetric determination of urea. Clin Chem;9: 102-108.

Cybulsky AV (2017): Endoplasmic reticulum stress, the unfolded protein response and autophagy in kidney diseases Nat. Rev. Nephrol;13: 681-696

Demirci K, Nazıroğlu M, Övey İS, et al., (2017): Selenium attenuates apoptosis, inflammation and oxidative stress in the blood and brain of aged rats with scopolamine-induced dementia. Metab Brain Dis;32(2): 321-329.

Diamond GL (2005): Risk assessment of nephrotoxic metals. In: Tarloff J, Lash L, eds. The toxicology of the kidney. London: CRC Press; 1099-1132.

Ding X, Ma M, Teng J, et al., (2016): Numb Protects Human Renal Tubular Epithelial Cells from Bovine Serum Albumin-Induced Apoptosis Through Antagonizing CHOP/PERK Pathway. J Cell Biochem;117(1): 163-71. 
Ekong EB, Jaar BG, Weaver VM. (2006): Lead-related nephrotoxicity: a review of the epidemiologic evidence. Kidney Int; 70: pp.2074

El-Ghazaly MA, Fadel N, Rashed E, et al., (2016): Anti-inflammatory effect of selenium nanoparticles on the inflammation induced in irradiated rats. Can J Physiol Pharmacol;95(2):101-110.

Flora SJ, and Pachauri V (2010): Chelation in metal intoxication. Int J Environ Res Public Health; 7: 2745-88

Fioresi M, Simões MR, Furieri LB, et al., (2014): Chronic Lead Exposure Increases Blood Pressure and Myocardial Contractility in Rats. PLoS ONE; 9(5): e96900.

Gao D, Xu Z, Zhang X, et al., (2013): Cadmium triggers kidney cell apoptosis of purse red common carp (Cyprinus carpio without caspase8 activation. Dev Comp Immunol; 41: 728-737.

Green DR, and Llambi F (2015): Cell death signaling Cold Spring Harb. Perspect. Biol;7: a 006080

Harding HP, Zhang Y, Bertolotti A, et al., (2000): Perk is essential for translational regulation and cell survival during the unfolded protein response. Mol Cell;5(5): 897-904.

Huang Y, Sun Y, Cao Y, et al., (2017): HRD1 prevents apoptosis in renal tubular epithelial cells by mediating eIF2alpha ubiquitylation and degradation. Cell Death Dis; 8: 3202.

Iglesias P, Selgas R, Romero S, et al., (2013): Selenium and kidney disease. J Nephrol; 26: 266-72.

Jin Z, and El-Deiry WS (2005): Overview of cell death signaling pathways Cancer Biol. Ther;4: 139-163.

Kiełczykowska M1, Kocot J, Lewandowska A, et al.,(2015): The protective influence of selenium on oxidant disturbances in brain of rats exposed to lithium. Physiol Res;64(5): 739-46.

Koracevic D, Koracevic G, Djordjevic V, et al., (2001): Method for the measurement of antioxidant activity in human fluids. J Clin Pathol;54(5): 356-61.

Larsen K (1972): Creatinine assay in the presence of protein with LKB8600 Reaction Rate Analyser. Clin Chim Acta;38: 475-476

Lin JL, Tan DT, Hsu KH, et al., (2001): Environmental lead exposure and progressive renal insufficiency. Arch Intern Med; 161: 264-71.

Liu X, Lv Z, Zou J, et al.,(2016): Afatinib downregulates MCL-1 expression through the PERKeIF2 $\alpha$-ATF4 axis and leads to apoptosis in head and neck squamous cell carcinoma Am. J. Cancer Res ;6: 1708-1719.

Makropoulos W, Heintz B, Stefanidis I (1997): Selenium deficiency and thyroid function in acute renal failure. Ren Fail; 19: 129-36.

Missoun F, Slimani M and Aoues A (2010): Toxic effect of lead on kidney function in rat Wistar. African Journal of Biochemistry Research;4(2): 21-27.

Nikolas CP, Eleftheria GH, Stamatis B, et al., (2005): Aristidis MT. Lead toxicity update: A brief review. Med Sci Monit;11:RA329-36.
Ogbechi J, Hall BS, Sbarrato T, et al., (2018): Inhibition of Sec61-dependent translocation by mycolactone uncouples the integrated stress response from ER stress, driving cytotoxicity via translational activation of ATF4. Cell Death Dis;9(3): 397.

Ohkawa H, Ohishi W, Yagi K. (1979): Anal. Biochem; 95,351

Orisakwe OE (2014): Lead and cadmium in public health in Nigeria: physicians neglect and pitfall in patient management. N Am J Med Sci; 6: pp.61-70.

Oyadomari S, and Mori M. (2004): Roles of CHOP/GADD153 in endoplasmic reticulum stress. Cell Death Differ;11: 381-389.

Walter P, and Ron D (2011): The unfolded protein response: from stress pathway to homeostatic regulation Science;334: 1081-1086.

Rastogi SK (2008): Renal effects of environmental and occupational lead exposure. Indian J Occup Environ Med;12(3): 103-106.

Rutkowski DT, and Kaufman RJ (2007): That which does not kill me makes me stronger: adapting to chronic ER stress. Trends Biochem Sci;32: pp.469-476.

Sears ME (2013): Chelation: harnessing and enhancing heavy metal detoxification-a review. ScientificWorld Journal; 2013: 219840.

Sharma V, Sharma A, Kansal L. (2010): The effect of oral administration of allium sativum extracts on lead nitrate induced toxicity in male mice. Food Chem Toxicol; 48: 928-36.

Silva NF, Pires JG, Campos RR, et al., (2001): Cardiovascular and respiratory responses to microinjection of L-glutamate into the caudal pressor area in conscious and anesthetized rats. Braz J Med Biol Res;34(12): 1603-6.

Soudani N, Troudi A, Bouaziz H, et al., (2011): Cardioprotective effects of selenium on chromium (VI)-induced toxicity in female rats. Ecotoxicol Environ Saf;74: 513-520.

Stanifer JW, Jing B, Tolan S, et al., (2014): The epidemiology of chronic kidney disease in subsaharan africa: a systematic review and metaanalysis. Lancet Glob Health; 2: e174-81.

Whitehead TP, Bevan EA, Miano L, et al., (1991): Defects in diagnostic kits for determination of urate in serum. Clin Chem;37: 879-881

Yin M, Jiang N, Guo L, et al., (2019): Oleuropein suppresses oxidative, inflammatory, and apoptotic responses following glycerol-induced acute kidney injury in rats. Life Sci;232: 116634

Zachara BA, Salak A, Koterska D, et al., (2004): Selenium and glutathione peroxidases in blood of patients with different stages of chronic renal failure. J Trace Elem Med Biol; 17: 291-9.

Zhang W, Xue J, Ge M, et al., (2012): Resveratrol attenuates hepatotoxicity of rats exposed to arsenic trioxide. Food Chem Toxicol; 51:87-92. 


\section{الحماية الكلوية للسيلينيوم من خلال منع مسار موت الخلايا المبرمج PERK-elf2a-CHOP فى ذكور} فئران التجارب المسممة بالرصاص

\section{مروة مدحت راشد' و منجود محمد الوكيل و محمد زكى حسين' و وسام مصطفى البقلى ‘ \\ الملخص العربي}

المقدمة: يمثل التلوث بالرصاص مصدر تهديد لكافة الوظائف الحيوية فى جسم الإنسان حيث يؤدي وجوده في الجسم إلى تأثثرات

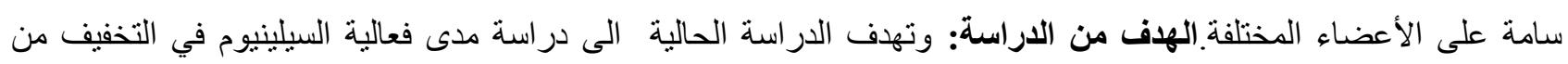
إصابة الكلى والإجهاد التأكسدي الناجم عن التسمم بالرصاص فى ذكور الفئران بالإضافة إلى دراسة الآليات الجزيئية المستخدمة. طريقة البحث: قد تم إختبار مدى فاعلية السيلينيوم فى الحماية من تسمم الكلى بالرصاص عن طريق قياس وظائف الكلى في ذكور

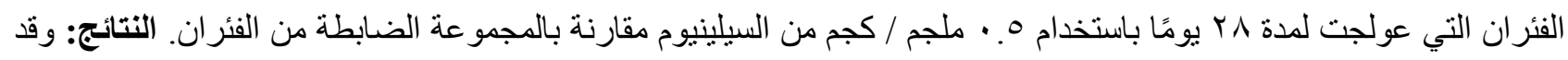

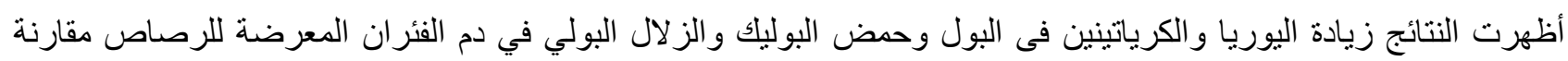
بالمجمو عة الضابطة وهو ما أكدته التغير ات الباثولوجية لأنسجة الكلى. كما أثنتت القياسات زيادة كبيرة في موت التيات الخلايا المبرمج بالإضافة إلى الفسفرة PERK و PE2a و البروتينات المبرمجة مثل CHOP و 3 و 3 و 1 و في الكلى للجرذان المعرضة للتسمم بالرصاص ، والتي تم تخفيفها عن طريق العلاج بالسيلينيوم. الاستنتاج: واستنتج من هذه الدراسة أن السيلينيوم يقلل من تسمم الكلى بالرصاص جزئيًا من خلال تثبيط مسار PERK- eIF2

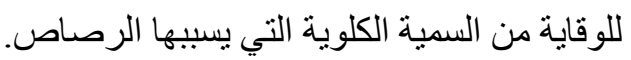

